\title{
撤去コンクリート電柱を用いた再生骨材コンクリートの性状に関する研究 PROPERTIES OF CONCRETE USING RECYCLED AGGREGATE MADE FROM USED CONCRETE POLE
}

\author{
小山明男 ${ }^{* 1}$, 濱田康平 ${ }^{* 2}$, 本間 雅 ${ }^{* 3}$, 菊池雅史 ${ }^{* 4}$ \\ Akio KOYAMA, Kohei HAMADA, Masato HONMA \\ and Masafumi KIKUCHI
}

\begin{abstract}
In this study, a series of experiments has been carried out to examine the properties of concrete using recycled aggregate made from used concrete pole. As the result, followings has been found. 1) The quality of recycled coarse aggregate made from used concrete poles corresponds to the recycled aggregate class M. 2) The hardened properties of recycled aggregate concrete can be significantly improved by the centrifugal compaction and the steam curing. 3) There is a possibility that recycled aggregate made from used concrete pole can be applied for the concrete utility pole, if natural aggregate is replaced with a part of recycled aggregate.
\end{abstract}

Keywords : Recycle, Centrifugal Cast, Steam Curing, Recycled Aggregate, Quality Control リサイクル, 遠心成形, 蒸気養生, 再生骨材, 品質管理

\section{1. はじめに}

コンクリート塊は，主に舗装用路盤材として $100 \%$ に近い量が再資 源化されている。しかし，1998 年をピークに公共事業費における道 路投資額の削減が顕著となり, 路盤材需要にのみ頼った再資源化では, 今後増加が見込まれているコンクリート塊の処理に支障をきたすこ とが予想される。このような中，コンクリート塊をコンクリート構造 物に利用する再生骨材コンクリートへの用途転換に対する期待は大 きい。このような観点から近年では再生骨材およびそれを用いたコン クリートに関する様々な技術開発が進み $\left.{ }^{1)}-3\right)$, JIS が制定された ${ }^{4)}$ 。

一方，コンクリート製品である電柱は，建築物として利用されるも のに比べれば少ないものの，年間の撤去量は 20 万トンといわれてお り，撤去された電柱（以下，撤去電柱と略す）のリサイクルに取り組 むことは, 資源循環型社会形成を目指寸わが国において意義は大きい。

ところで，電柱などの遠心製品から製造された再生骨材は，JIS A 5021 「コンクリート用再生骨材 $\mathrm{H} 」$ からは除外されている。その理由 として, 現状の破砕技術によって遠心製品から得られる再生骨材は, 吸水率が小さくても付着セメントペーストが多くなり, 収縮ひび割れ に対する懸念など,一般のコンクリート塊から得られる再生骨材に比 べて技術資料が整っていないことに起因している。

しかしながら, 撤去電柱は, 製造場所や使用材料など履歴が比較的
明確な事, 高強度コンクリートが使用されている事など, 再生骨材と して利用しようとする際に, 解体建築物由来のコンクリート塊よりも 有利な点も多くある。そこで筆者らは，このような特色を持つ撤去電 柱由来の再生骨材を, 電柱を主としたコンクリート二次製品に還元す ることを目標とし, この種の再生骨材およびそれを用いたコンクリー トの基礎的性状について実験的に検討を行っている5

本報では, 製造年および使用場所が把握可能な撤去電柱を用いた再 生骨材の品質試験結果ならびに再生骨材コンクリートのフレッシュ 性状，硬化性状および而久性に関する実験結果について報告する。ま た, 再生骨材コンクリート電柱の実用化および安定生産に向けた基礎 資料として, 再生骨材の品質・変動とそれが再生骨材コンクリートに 及ぼす影響の検討結果について報告する。

\section{2. 本研究に用いた再生骨材の特性}

\section{1 原コンクリートの物性}

原コンクリートの強度を調査するために, 現在数多く排出されてい る 1960１970 年代の撤去電柱の圧縮強度試験を行った。供試体は, 撤去電柱の外観状態を目視にて確認し, 横ひび割れ, 縦ひび割れとも に無く, 比較的良好な状態の部分を切り出して製造した。

試料数 9 体の圧縮強度試験結果は, $58 \sim 80 \mathrm{~N} / \mathrm{mm}^{2}$ (平均: $72.0 \mathrm{~N} / \mathrm{mm}^{2}$ )
$* 1$ 明治大学理工学部建築学科 准教授 $\cdot$ 博士 $($ 工学 $)$

$* 2$ 明治大学大学院理工学研究科新領域創造専攻

*3 日本コンクリート工業(侏)

$* 4$ 明治大学理工学部建築学科 教授.工博
Assoc. Prof., School of Science and Technology, Meiji Univ., Dr. Eng. Graduate Student, Department of Science and Technology, Meiji Univ. Research Institute, Nippon Concrete Industries Co., Ltd.

Prof., School of Science and Technology, Meiji Univ., Dr. Eng. 
であった。1960〜1970 年代当時の設計基準強度は 49N/mm² であるが， それをかなり上回り, 再生骨材用の原コンクリートとしては, 非常に 高強度のコンクリートである。

\section{2 再生骨材の製造方法}

写真 1 に再生骨材の製造方法を示す。装置および製造フローは再生 路盤材の製造に実稼働しているものを利用した。電力・通信会社によ って改修された撤去電柱を重機にて適当な長さに切断（写真 1 の (1) した後，同機で 1 次粗破砕して鋼材の分別（写真 1 の(2) を行った。 その後，インパクトクラッシャーにより 2 次破砕（写真 1 の(3)）し， 同時に磁選機にかけて鋼材を除去して，再生路盤材に使用される 40-0mm の骨材（写真 1 の(5)）が得られる。最後に，JIS A 5005 に規 定されている砕石 1505 相当の粒度に適合寸るようにふるいをかけ粒 度調整したものを再生粗骨材（写真 1 の(6)），また $5 \mathrm{~mm}$ 以下のもの を再生細骨材（写真1の(4)）として使用した。なお，水洗いおよびす りもみ等の高度処理は行っておらず，簡易な製造方法であり，既報 のとおり製造にかかる環境負荷は砕石や再生骨材 L と同等である。

\section{3 再生骨材の物性および品質}

\section{(1) 骨材試験試料の採取方法}

再生骨材の品質変動の把握を目的に, 再生骨材を製造した 2 ケ月間 において，数日おきに合計 11 回骨材試験用の試料を採取した。各日 の試料骨材は，野積みにされた再生骨材から，少なくとも円周上の 2 籄所において, 上・中・下部から均等に採取し, 計 $100 \mathrm{~kg}$ 程度とした。

\section{（2）骨材試験項目および試験方法}

骨材試験項目およびその方法は，表 1 に示すとおりである。

\section{(3) 骨材試験結果および考察}

表 2 に骨材試験結果を示す。本研究で製造した再生骨材の吸水率は, 粗骨材が $4.47 \%$ で JIS の再生骨材 M 相当，細骨材が $9.07 \%$ となり JIS の再生骨材 $\mathrm{L}$ 相当であった。破砕処理のみによって製造される再生 骨材としては，かなり吸水率が小さいが，これは原コンクリートの強 度が $60 \sim 80 \mathrm{~N} / \mathrm{mm}^{2}$ の高強度であったことに起因する。

また, 表 2 の標準偏差をみると, 製造日の異なる再生骨材物性の変 動はそれほど大きくない。これは, 原コンクリートの製造年代が 1960 〜1970 年代とほぼ限定されていたためと考えられる。ただし，電柱 のコンクリート設計基準強度は増加傾向にあり，近年の $100 \mathrm{~N} / \mathrm{mm}^{2}$ 近いものが撤去され出して, コンクリート設計基準強度が大きく異な る電柱が混在するようになった場合には，注意を要す可能性もある。

図 2 に再生粗骨材の吸水率とモルタル付着率の関係を示寸。本研究 で用いた再生骨材のほかに，既報告の結果 ${ }^{7)}$ も合わせて示した。本 研究の再生粗骨材のモルタル付着率は平均で $44.7 \%$ あ゙り, 既往研究 における同等の吸水率の再生粗骨材に比べてモルタル付着率は大き い。また, 図 3 に再生細骨材の吸水率とペース卜付着率の関係を示す。 再生細骨材のペース卜付着率は平均で $32.8 \%$ であり, 既往研究との比 較による傾向は, 再生粗骨材の場合と同様であった。これらの傾向は, 本研究で用いた再生細・粗骨材ともに原コンクリートが高強度である ことに起因している。

\section{3． 再生骨材コンクリートの基礎性状}

\section{1 実験概要}

\section{(1) 使用材料}

表 3 に本研究で使用した材料の概略を示す。再生骨材は, 2.と同一

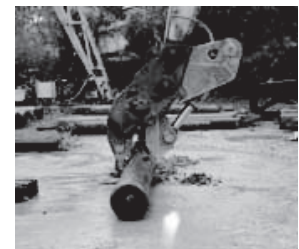

(1) 粗破砕

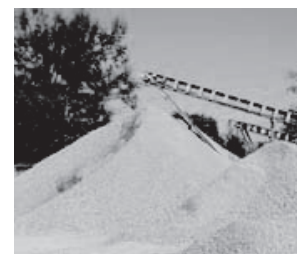

(4) 再生細骨材

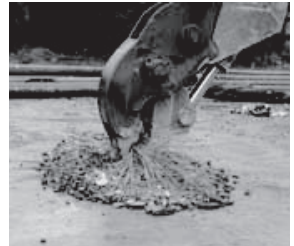

(2) 鋼材の分別

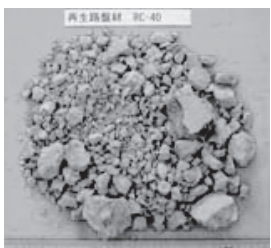

(5) 再生路盤材

写真 1 再生骨材の製造方法

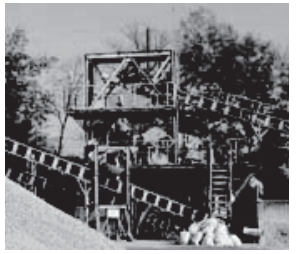

(3) コンクリート破砕

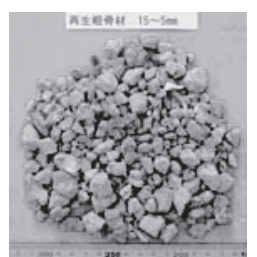

(6) 再生粗骨材
表 1 骨材試験項目および方法

\begin{tabular}{|c|c|}
\hline 試験項目 & 試験方法 \\
\hline 密度および吸水率 & JIS A 1110(粗骨材の密度および吸水率試験方法) \\
\hline 実積率 & JIS A 1109(細骨材の密度および吸水率試験方 \\
\hline 微粒分量 & JIS A 1103(骨材の微粒分量試験方法) \\
\hline $\begin{array}{l}\text { モルタル付着率 } \\
\text { (ペースト付着率) }\end{array}$ & 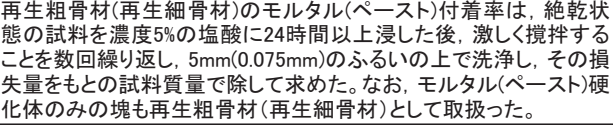 \\
\hline
\end{tabular}

表 2 骨材試験結果

\begin{tabular}{c|c|c|c}
\hline \multicolumn{2}{|c|}{} & 平均 & 標準偏差 \\
\hline \multirow{3}{*}{ 粗 } & モルタル付着率 $(\%)$ & 44.7 & 0.83 \\
\cline { 2 - 4 } 骨 & 微粒分量 $(\%)$ & 1.07 & 0.33 \\
\cline { 2 - 4 } 材 & 実積率 $(\%)$ & 59.3 & 1.09 \\
\cline { 2 - 4 } & 絶乾密度 $\left(\mathrm{g} / \mathrm{cm}^{3}\right)$ & 2.40 & 0.03 \\
\cline { 2 - 4 } & 吸水率 $(\%)$ & 4.47 & 0.40 \\
\hline \multirow{3}{*}{ 細 } & ペース卜付着率 $(\%)$ & 32.8 & 1.49 \\
\cline { 2 - 4 } 骨 & 微粒分量 $(\%)$ & 5.04 & 1.10 \\
\cline { 2 - 4 } 材 & 実積率 $(\%)$ & 69.69 & 3.93 \\
\cline { 2 - 4 } & 絶乾密度 $\left(\mathrm{g} / \mathrm{cm}^{3}\right)$ & 2.11 & 0.05 \\
\cline { 2 - 4 } & 吸水率 $(\%)$ & 9.07 & 0.90 \\
\hline \multicolumn{3}{|c}{} &
\end{tabular}

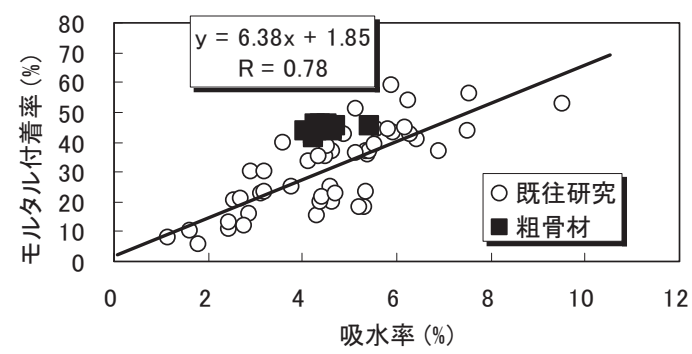

図 2 再生粗骨材の吸水率とモルタル付着率の関係

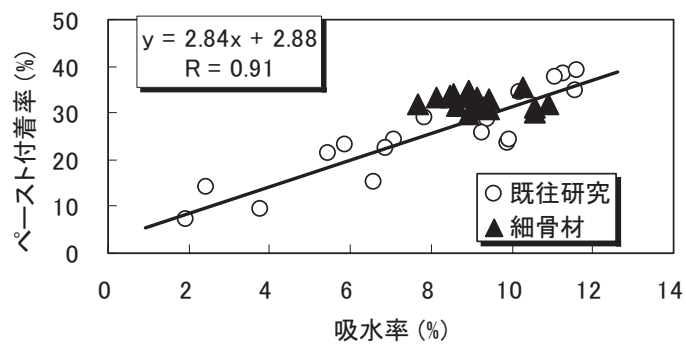

図 3 再生細骨材の吸水率とペース卜付着率の関係

のものを用いた。粗粒率は, 打設前にJISに準じて試験を行い求めた。

\section{（2）試験体水準}

試料コンクリート種類および調合概略を表 4 に示す。シリーズ I 
では, 水セメント比と圧縮強度の関係把握を目的に, 水セメント比 および再生粗骨材置換率を変動因子とした。水セメント比および再 生粗骨材置換率ごとに試練りを行い, 細骨材率および単位水量を決 定した。シリーズ II では, 強度や耐久性に及ぼす再生骨材置換率の 影響把握を目的に, 各水セメント比で細骨材率および単位水量を一 定とし, 水セメント比, 再生細・粗骨材置換率を変動因子とした。

\section{（3）試験体作製方法}

図 4 に示寸ように, 試験体は, (1)振動成形で標準養生したもの（以 下，振動標準），(2遠心成形で蒸気養生したもの（以下，遠心蒸気） および(3)振動成形で蒸気養生（以下，振動蒸気）したものの計 3 種類 の製造方法とした。蒸気養生は図 5 の工程で行った。遠心成形では既 存の製品と同じ回転数で製造した。また本研究では遠心成形製品の適 用を想定しており，空気量については特別な調整を行っていない。

\section{（4）試験方法}

表 5 に試験項目および試験方法を示す。

\section{2 フレッシュ性状}

図 6 に, スランプを一定とした場合の再生粗骨材置換率と単位水量 の関係を示す。単位水量によりスランプを調整する場合, 再生粗骨材 置換率の増加に伴い単位水量が増加する傾向にある。ただし, シリー ズ II 実験では, 再生骨材置換率増加に伴い減水剤添加率を調整するこ とで，スランプを調整することは可能であった。なお，練り混ぜ直後 のスランプは一定值を確保できるものの, 再生骨材置換率が大きくな るとスランプロスがやや増加する傾向が認められた。

\section{3 強度性状}

図 7 に振動成形した試験体の圧縮強度を示す。電柱用コンクリート の管理材齢 14 日において, 標準養生または蒸気養生のいずれの試験 体でも, 再生骨材置換率が大きくなるに従って圧縮強度の低下がみら れる。また，再生細骨材を用いたコンクリートでは，W/C=45\%の場 合でも再生細骨材置換率の増加にともなう圧縮強度の低下が顕著で あり，再生細骨材の吸水率が高いことによる影響が認められる。

蒸気養生の試験体の圧縮強度は, 振動標準の同材齢と比較して, 10 $\sim 15 \mathrm{~N} / \mathrm{mm}^{2}$ 程度低い結果となった。平井らは, 蒸気養生による細孔量

表 5 試験項目および試験方法

\begin{tabular}{|c|c|c|}
\hline \multicolumn{2}{|c|}{ 試験項目 } & 試験方法 \\
\hline \multirow{3}{*}{ フレッシュ性状 } & スランプ & JIS A 1101 \\
\hline & 単位容積質量 & JIS A 1116 \\
\hline & 空気量 & JIS A 1128 \\
\hline \multirow{2}{*}{ 強度 } & 圧縮強度 & $\begin{array}{l}\text { JIS A } 1108 \\
\text { JIS A } 1136\end{array}$ \\
\hline & ヤング係数 & JIS A 1149 \\
\hline \multirow{5}{*}{ 耐久性 } & \multirow{3}{*}{ 乾燥収縮率 } & JIS A 1129-1(振動標準の試験体) \\
\hline & & JIS A 1129-2(遠心蒸気の試験体) \\
\hline & & JIS A 1129-3(振動蒸気の試験体) \\
\hline & 中性化深さ & JIS A 1153 \\
\hline & 凍結融解抵抗性 & JIS A 1148 \\
\hline
\end{tabular}

表 3 使用材料概略

\begin{tabular}{c|c|c}
\hline 使用材料 & 材料名 & 性質 \\
\hline セメント & 普通ポルトランドセメント & 密度: $3.16 \mathrm{~g} / \mathrm{cm}^{3}$ \\
\hline \multirow{2}{*}{ 粗骨材 } & 再生粗骨材 1505 & 絶乾密度: $2.40 \mathrm{~g} / \mathrm{cm}^{3}$, 吸水率: $4.47 \%, F M: 6.91$ \\
\cline { 2 - 3 } & 下粕尾産硬質砂岩砕石 $13 \mathrm{~mm}$ & 絶乾密度: $2.64 \mathrm{~g} / \mathrm{cm}^{3}$, 吸水率: $0.64 \%, F M: 6.41$ \\
\hline \multirow{2}{*}{ 細骨材 } & 再生細骨材 & 絶乾密度: $2.11 \mathrm{~g} / \mathrm{cm}^{3}$, 吸水率: $: 9.07 \%, F M: 3.32$ \\
\cline { 2 - 3 } & 岩瀬産硬質砂岩砕砂 & 絶乾密度: $2.59 \mathrm{~g} / \mathrm{cm}^{3}$, 吸水率: $: 1.20 \%, F M: 2.53$ \\
\hline 混和剂 & ナフタリンン系高性能減水剂 & 密度: $1.20 \mathrm{~g} / \mathrm{cm}^{3}$ \\
\hline
\end{tabular}

表 4 試料コンクリートの種類および調合概略（シリーズ I ， II ）

\begin{tabular}{|c|c|c|c|c|c|c|c|c|c|}
\hline & 試験体水準 & $\begin{array}{l}\text { 試験 } \\
\text { 項目 }\end{array}$ & $\begin{array}{c}\text { W/C } \\
(\%)\end{array}$ & $\begin{array}{c}\text { 再生 } \\
\text { 粗骨材 } \\
\text { 置換率 } \\
(\%)\end{array}$ & $\begin{array}{c}\text { 再生 } \\
\text { 細骨材 } \\
\text { 置換率 } \\
(\%)\end{array}$ & $\begin{array}{c}\text { 目標 } \\
\text { スラプ } \\
\text { (cm) }\end{array}$ & $\begin{array}{c}\text { 目標 } \\
\text { 空気量 } \\
(\%) \\
(\%)\end{array}$ & $\begin{array}{c}\text { 細骨 } \\
\text { 材率 } \\
(\%)\end{array}$ & $\begin{array}{c}\text { 単位 } \\
\text { 水量 } \\
\left(\mathrm{kg} / \mathrm{m}^{3}\right)\end{array}$ \\
\hline \multirow{16}{*}{$\begin{array}{c}\text { シ } \\
\text { リ } \\
\text { I } \\
\text { ズ } \\
\mathrm{I}\end{array}$} & RG27-25C & O & \multirow{3}{*}{27} & 25 & \multirow{16}{*}{0} & \multirow{16}{*}{$20 \pm 2$} & \multirow{16}{*}{$2 \pm 1.0$} & 44.3 & 181 \\
\hline & RG27-50C & 0 & & 50 & & & & 43.1 & 182 \\
\hline & RG27-100C & 0 & & 100 & & & & 40.9 & 185 \\
\hline & RG30-0C & O & \multirow{4}{*}{30} & 0 & & & & 47.6 & 178 \\
\hline & RG30-25C & O & & 25 & & & & 47.4 & 175 \\
\hline & RG30-50C & 0 & & 50 & & & & 46.4 & 176 \\
\hline & RG30-100C & 0 & & 100 & & & & 44.4 & 178 \\
\hline & RG33-25C & 0 & \multirow{3}{*}{33} & 25 & & & & 49.4 & 171 \\
\hline & RG33-50C & 0 & & 50 & & & & 48.4 & 172 \\
\hline & RG33-100C & 0 & & 100 & & & & 46.6 & 174 \\
\hline & RG35-50C & $\mathrm{O}$ & 35 & 50 & & & & 42.5 & 175 \\
\hline & RG36-0C & O & \multirow{4}{*}{36} & 0 & & & & 50.1 & 178 \\
\hline & RG36-25C & 0 & & 25 & & & & 51 & 167 \\
\hline & RG36-50C & O & & 50 & & & & 49.9 & 169 \\
\hline & RG36-100C & O & & 100 & & & & 48.2 & 171 \\
\hline & RG37-25C & O & 37 & 25 & & & & 42.5 & 175 \\
\hline & RG30-0NS & (2) & \multirow{4}{*}{30} & 0 & \multirow{14}{*}{0} & \multirow{8}{*}{$20 \pm 2$} & \multirow{17}{*}{$2 \pm 1.0$} & & \multirow{15}{*}{175} \\
\hline & RG30-25NS & (2) & & 25 & & & & 306 & \\
\hline & RG30-50NS & (2) & & 50 & & & & & \\
\hline & RG30-100NS & (2) & & 100 & & & & & \\
\hline & RG36-0NS & (2) & \multirow{4}{*}{36} & 0 & & & & & \\
\hline & RG36-25NS & () & & 25 & & & & & \\
\hline & RG36-50NS & (2) & & 50 & & & & $42 . J$ & \\
\hline リ & RG36-100NS & (2) & & 100 & & & & & \\
\hline 1 & RG41-50S & $\mathrm{O}$ & 41 & 50 & & \multirow{9}{*}{$18 \pm 2$} & & & \\
\hline 지 & RG43-25S & $\mathrm{O}$ & 43 & 25 & & & & & \\
\hline & RG45-0NS & (2) & \multirow{7}{*}{45} & 0 & & & & & \\
\hline & RG45-25NS & (?) & & 25 & & & & 45 & \\
\hline & RG45-50NS & (2) & & 50 & & & & & \\
\hline & RG45-100NS & (2) & & \multirow{4}{*}{100} & & & & & \\
\hline & RSG45-25NS & (2) & & & 25 & & & & \\
\hline & RSG45-50NS & (2) & & & 50 & & & 436 & 185 \\
\hline & RSG45-100NS & (2) & & & 100 & & & & \\
\hline
\end{tabular}

※打設·養生方法 (C: 遠心蒸気、NS:振動標準·振動蒸気、S:振動蒸気)

実施項目 ○: 圧縮強度＆耐久性 0 : 圧縮強度 $\mathrm{O}$ : 耐久性

ただしNSI関しては振動標準のみ耐久性試験を実施した。

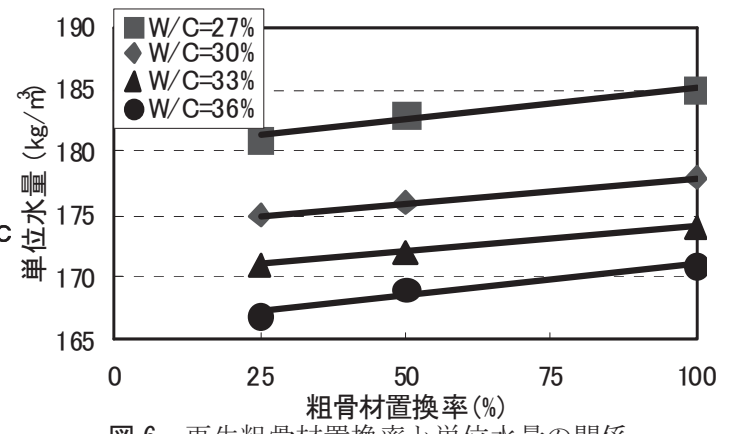

図 6 再生粗骨材置換率と単位水量の関係

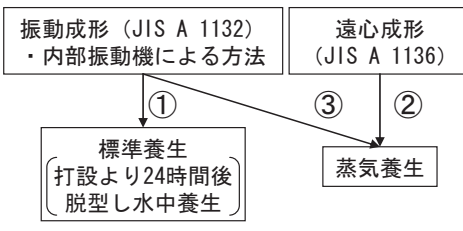

図 4 試験体作製方法

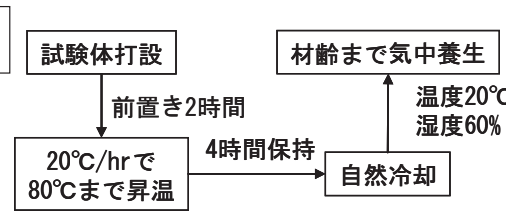

図 5 蒸気養生の工程 

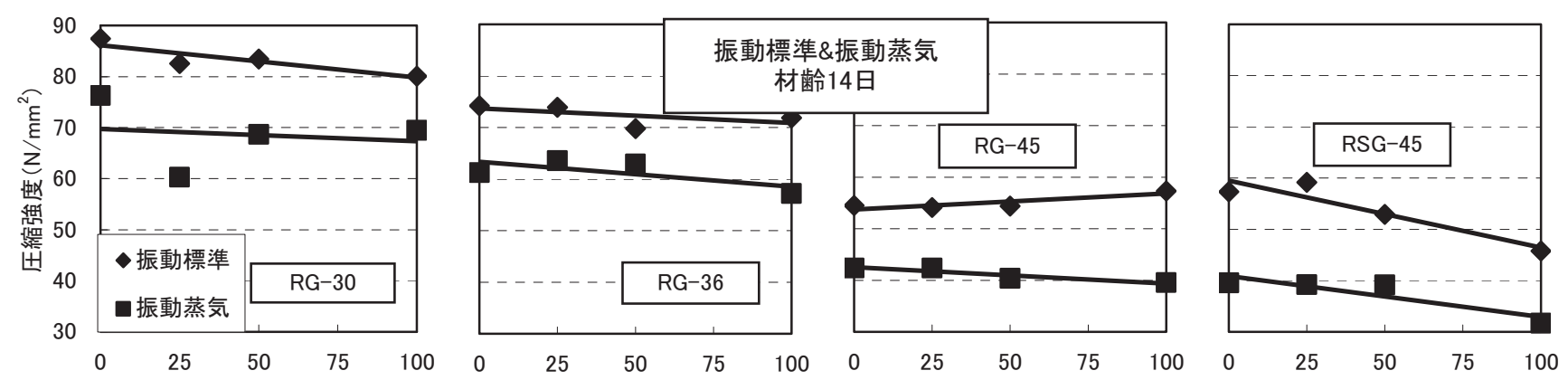

図 7 各水セメント比における再生骨材置換率と圧縮強度の関係（振動成形）
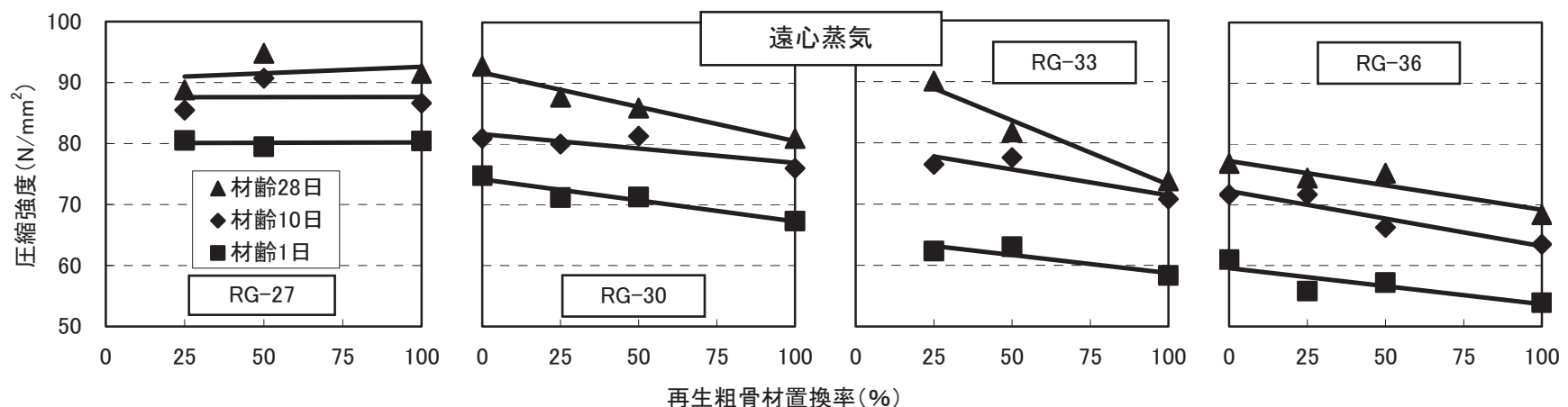

図 8 各水セメント比における再生粗骨材置換率と圧縮強度の関係（遠心成形）

の増加に伴い圧縮強度の低下を招くことを指摘している ${ }^{8)}$ が，本研 究の範囲においても同様の傾向を示した。

図 8 に遠心成形した試験体の再生粗骨材置換率と圧縮強度の関係 を示す。 $\mathrm{W} / \mathrm{C}=30 \%$ 以上のコンクリートでは，振動成形した場合と同 様に, 再生粗骨材置換率の増加による圧縮強度の低下がみられたが, $\mathrm{W} / \mathrm{C}=27 \%$ ではその傾向が認められなかった。これは，本実験の他範 囲の傾向や一般に指摘されていることと異なる結果であり,遠心成形 による骨材界面の組織の変化などを今後詳細に検討する予定である。

図 9 に遠心成形した試験体の圧縮強度とヤング係数の関係を示す。 図中には, $\mathrm{W} / \mathrm{C}=30 \%$ および $\mathrm{W} / \mathrm{C}=45 \%$ のときの供試体の単位容積質量 平均值の場合の NewRC 式による計算值を合わせて示した。遠心蒸気 とすることで組織が緻密化されるため, 本実験の範囲における再生骨 材コンクリートは, 高強度域においてもヤング係数が計算值より大き くなる傾向を示した。

\section{4 耐久性状}

\section{(1) 乾燥収縮率}

図 10 に振動成形および標準養生とした試験体の乾燥収縮率を示寸 再生粗骨材置換率 100\%としたコンクリートは, 普通コンクリートと 比較して $0.5 \times 10^{-4}$ 程度の収縮率の増加がみられた。また，再生細・ 粗骨材とも置換率 $100 \%$ とした再生骨材コンクリートは, 再生粗骨材 のみを $100 \%$ 置換したコンクリートに比べて $2 \times 10^{-4}$ 程度大きい乾燥 収縮率を示しており, 乾燥収縮に及ぼ寸再生細骨材の影響が強く認め られた。図 11 に製造方法（成形方法および養生方法）の異なる試験 体の材齢 26 週時の乾燥収縮率を示す。遠心蒸気において, 材齢 26 週での乾燥収縮率は $3 \times 10^{-4}$ 程度であり, 振動標準と比較すると, 乾 燥収縮率は $1 / 2$ 程度まで低減された。一方, $\mathrm{W} / \mathrm{C}=45 \%$ の試験体によ って振動標準と振動蒸気を比較すると, 蒸気養生によって乾燥収縮率 が $2 \times 10^{-4}$ 低い值となっていることが確認できる。これらのことから，

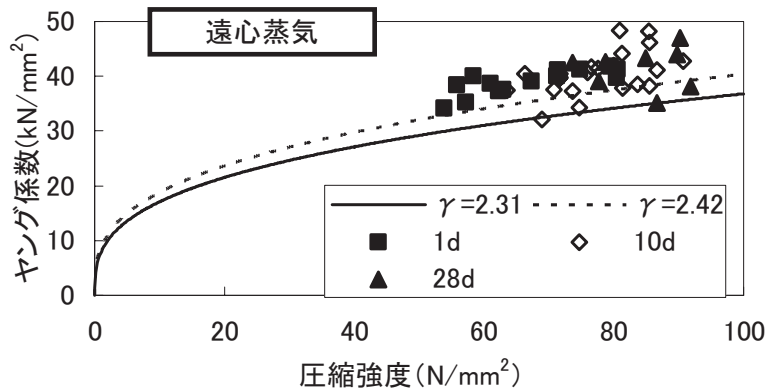

図 9 圧縮強度とヤング係数の関係（遠心蒸気）

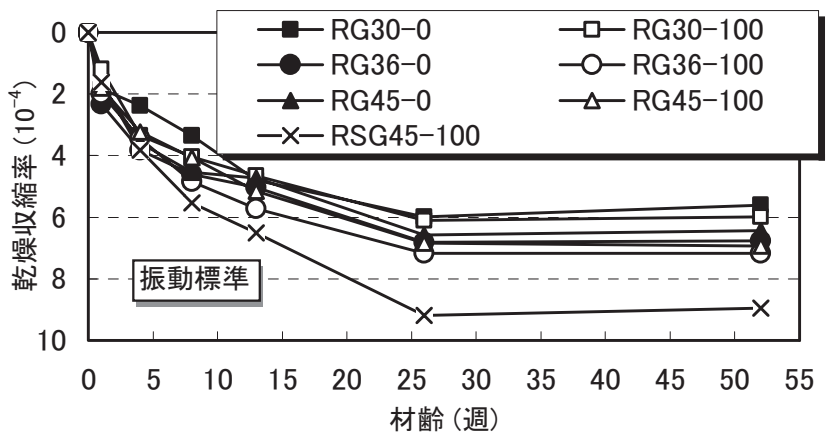

図 10 材齢と乾燥収縮率の関係（振動標準）

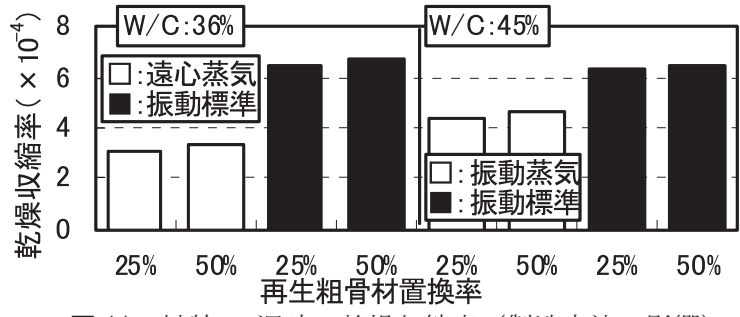

図 11 材齢 26 週時の乾燥収縮率 (製造方法の影響) 
遠心成形した再生骨材コンクリートでは, 遠心成形による組織の緻密 化にともない乾燥収縮率が低減すると考えられるが, 蒸気養生による 影響も大きいといえる。ただし, 本研究の範囲の再生骨材コンクリー 卜は低水セメント比であるため, 自己収縮が大きくなることが懸念さ れ, 電柱への適用を考えるとプレストレス導入への影響などをクリー プ試験などによって確認する必要がある。

\section{（2）促進中性化}

図 12 に各種試験体の中性化深さの関係を示す。振動標準において, 同一促進期間における中性化深さは, 水セメント比の影響を大きく受 けるが，同一水セメント比においては，再生粗骨材置換率の増加によ る中性化深さの増加傾向はみられなかった。ただし，再生細骨材を混 入することでの中性化深さの増加傾向は認められた。

$\mathrm{W} / \mathrm{C}=36 \%$ の遠心蒸気においては促進26週までに中性化していない また, 振動蒸気とした $\mathrm{W} / \mathrm{C}=41 \%$ の中性化深さは, $\mathrm{W} / \mathrm{C}=45 \%$ の振動標 準の試験体と比較して大きい。これは，阿波ら ${ }^{9)}$ が指摘していると おり蒸気養生によって表層に微細ひび割れが発生することに起因し ていると考えられる。これらのことから, 遠心成形は, 中性化に対し て非常に効果があるといえる。

\section{（3）凍結融解抵抗性}

図 13 にサイクル数と相対動弾性係数の関係を示す。いずれの水準 とも振動標準で, 空気量は $2 \%$ 以下の NonAE コンクリートである。 そのため相対動弾性係数は，ほとんどの水準が 300 サイクル以前に 60\%以下に低下したが, 本研究の範囲では, 水セメント比の低減によ り而凍結融解性は改善されることが確認できた。

\section{4. 再生骨材コンクリートの品質変動}

\section{1 実験概要}

実用化一向けた検討として, 再生骨材の品質変動を考慮した場合の コンクリートの品質変動について検討を行った。シリーズ I , II の試 験結果を用い, $\mathrm{C} / \mathrm{W}$ と圧縮強度の回帰式を算定し, 調合強度を $65 \mathrm{~N} / \mathrm{mm}^{2}$ または $40 \mathrm{~N} / \mathrm{mm}^{2}$ として, 再生粗骨材置換率に応じて水セメ ント比を設定した。モルタル付着率を再生粗骨材の品質変動の代表值 とした。モルタル付着率の標淮偏差の 2 倍 $(1.66 \%)$ を再生粗骨材置 換率として増減させ，さらに JIS A 5308 においての骨材許容計量誤差 3\%を考慮して,これらを合計した $4.66 \% \rightarrow \pm 5 \%$ を再生粗骨材置換率 $50 \%$ のとの試験水準とした。置換率 $25 \%$ においも同様に仮定して 置換率士3\%を試験水準とした。表 6 に調合概略を示す。なお，使用 材料はシリーズ I およびシリーズII と同じである。

\section{2 試験項目および試験方法}

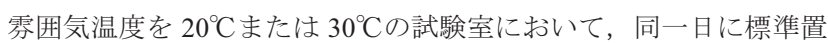
換率および増減分をそれぞれ 4 回，合計 12 回ランダムに試験した。 試験項目は, フレッシュコンクリートのスランプ, 空気量および単位 容積質量, 硬化コンクリートの圧縮強度およびヤング係数を各 JIS に 準じて試験した。なお，コンクリートの練混ぜ状況を観察しながら， 減水剂添加率を若干変動させている。

\section{3 試験結果および検討}

\section{（1）フレッシュ性状}

RG-65N-25 のスランプ試験結果を図 14 に，RG-65N-50 を図 15 に 示す。RG-65N-25 は䨌囲気温度条件によらずスランプを精度良く管理

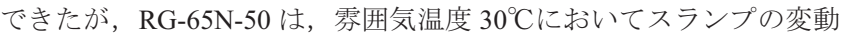

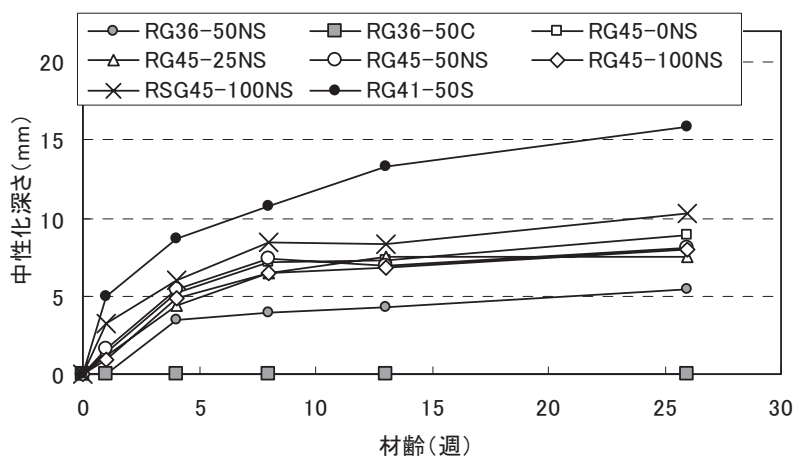

図 12 材齢と中性化深さの関係

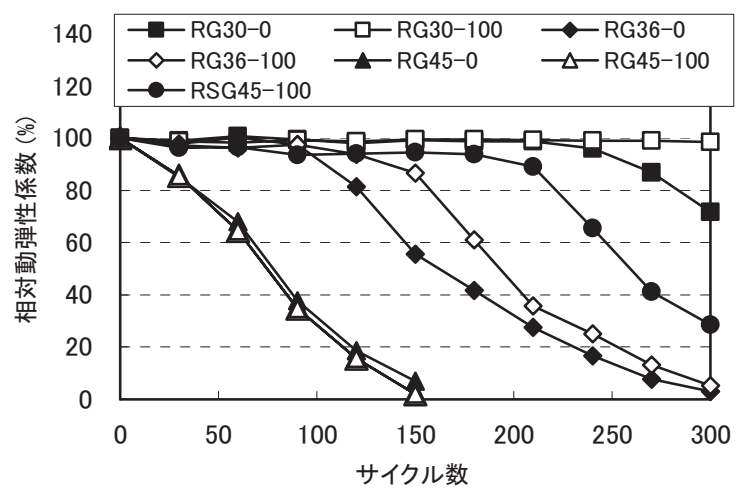

図 13 凍結融解試験結果（振動標準）

表 6 試料コンクリートの種類および調合概略(シリーズIII)

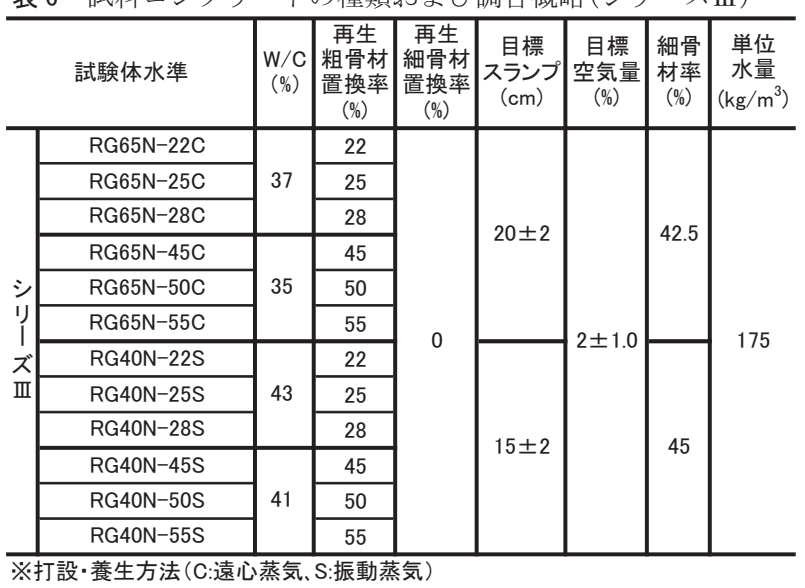

が大きかった。なお，RG-40N-25，RG-40N-50 においても RG-65N-25 と同様，良好にスランプの調整が可能であることが確認できた。また 空気量, 単位容積質量については, いずれの水準でも特別な調整を行 っていなかったが，精度よく管理できた。

\section{(2) 圧縮強度}

RG-65N-50 の材齢 14 日の圧縮試験結果を図 16 に，RG-40N-50を 図 17 に示す。いずれにおいても標準偏差は小さく, 天然骨材を用い た電柱製造工場の標準偏差と同等であった。また， RG-65N-25， RG-40N-25 においても強度レベルや䨌囲気温度による影響は小さく, 管理材歯内に所定の強度が得られた。

\section{5. 結論}

本研究の結果をまとめると大要以下のことがいえる。

（1）簡易破砕によって得られる撤去電柱由来の再生骨材は，粗骨材 
で再生粗骨材 M，細骨材で再生細骨材 L に相当する。

（2）再生骨材置換率の増加にともなって，同一スランプを得るため の単位水量は大きくなるが, 単位水量を一定としても減水剂の 添加率を調整することでも対応できる。

（3）再生骨材コンクリートの圧縮強度は，遠心成形した場合でも， 一般的な再生骨材コンクリートと同様に，再生骨材置換率が大 きくなるに従って低下する。

（4）遠心成形および蒸気養生によって, 再生骨材コンクリートの乾 燥収縮は小さく抑えることができる。

（5）遠心成形によって再生骨材コンクリートは維密化されるため, その中性化抑制効果は大きい。

（6）NonAE であっても，再生骨材コンクリートの耐凍結融解性は, W/C を低減することで若干改善できる。

（7）再生骨材の品質変動を考慮しても，再生骨材コンクリートの品 質変動は小さく，実用化が可能な範囲にある。ただし，夏季の スランプ変動については十分な注意が必要である。

（8）再生粗骨材のみを使用し，置換率 $50 \%$ 以内であれば電柱用コン クリートとして再生骨材活用の可能性は高い。

\section{謝辞}

実験の実施にあたり，2007 年度明治大学大学院修了生の沖倉大善 氏をはじめとした本研究室所属の学生諸氏に多大なご協力を頂きま した。ここに厚く謝意を表します。

\section{参考文献}

1）江口清ほか：低環境負荷型再生コンクリートの実用化に関する研究, 日本建築学会構造系論文集，NO.570，pp.15-21，2003.8

2）田村雅紀, 野口貴文, 友澤史紀 : セメント回収型完全リサイクルコン クリートの完全リサイクル住宅(SPRH)への実施工検討, 日本建築学会 技術報告集，第 21 号，pp.27-32，2005.6

3）石倉武，曽根德明，立屋敷久志，友澤史紀，嵩英雄：高品質再生骨材 の原子力発電所マスコンクリートへの適用, 日本建築学会技術報告集, 第 22 号，pp.39-42，2005.12

4）野口貴文，小山明男，鈴木康範：再生骨材および再生骨材コンクリー トに関する JIS 規格，コンクリート工学，Vol.45，No.7，pp.5-12, 2007.7

5）沖倉大善ほか：撤去電柱から製造される再生骨材を用いたコンクリー 卜の基礎性状に関する実験的研究, 日本建築学会大会学術講演梗概集, A-1， pp.141-142, 2007.8

6）小山明男，濱田康平，沖倉大善，本間雅人：撤去電柱を用いた再生骨 材コンクリートの品質および環境影響評価, JCI 環境時代におけるコ ンクリートイノベーションに関するシンポジウム論文集，pp.19-24， 2008.8

7）小山明男：JIS A 5022（再生骨材 M を用いたコンクリート）制定され る，標準化ジャーナル，Vol.37, pp.3-7, 2007.6

8）平井和喜, 成田健: セメントモルタルの細孔分布に及ぼす初期恒温養 生の影響, コンクリート工学年次論文報告集, 9-1, pp. 163-168, 1987

9）阿波稔ほか: 蒸気養生過程で発生する鉄筋コンクリート部材の微細ひ びわれ，コンクリート工学年次論文報告集, Vol. 15, No.1, pp. 567-572, 1993

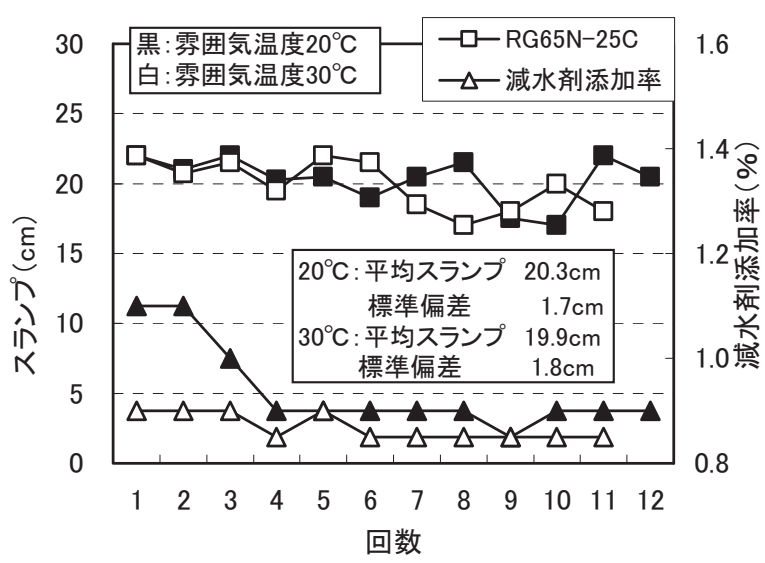

図 14 スランプの品質変動（RG-65N-25）

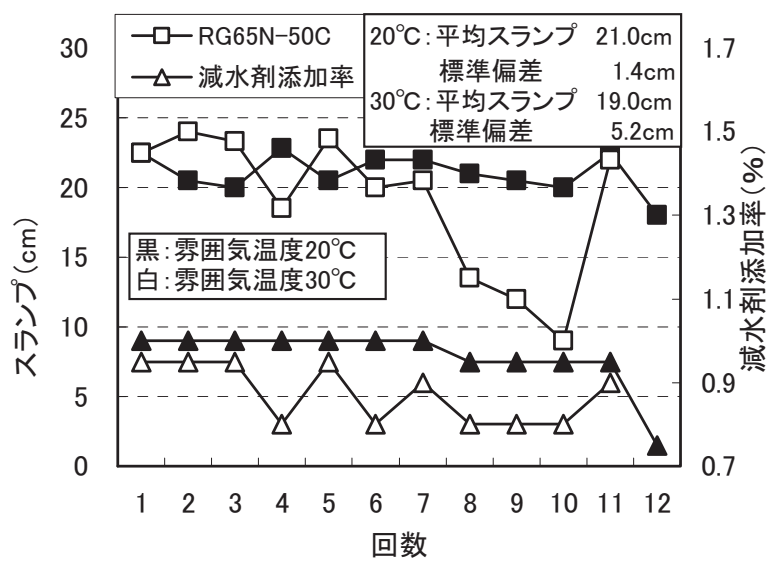

図 15 スランプの品質変動（RG-65N-50）

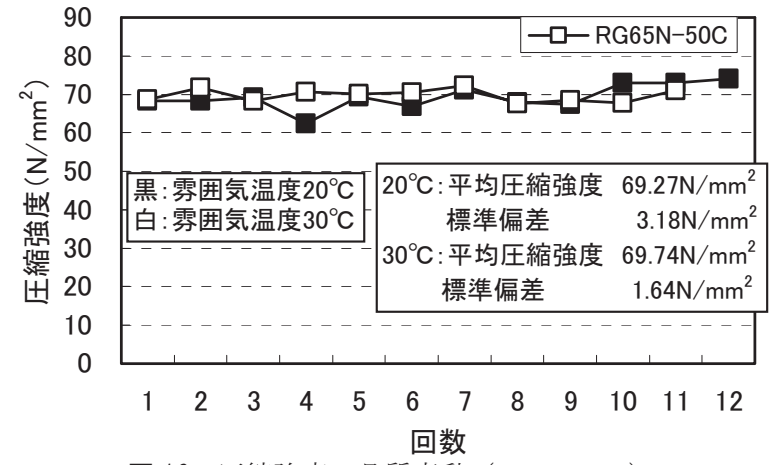

図 16 圧縮強度の品質変動（RG-65N-50）

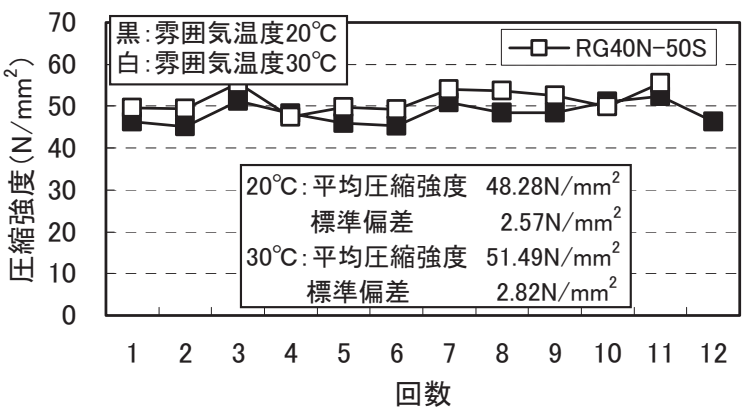

図 17 圧縮強度の品質変動（RG-40N-50）

(2009年 3 月 10 日原稿受理, 2009 年 6 月 8 日採用決定) 